Marta S. Basualdo · Diego Feroldi

Rachid Outbib

Editors

\title{
PEM Fuel Cells with Bio-Ethanol Processor Systems
}

A Multidisciplinary Study of Modelling, Simulation, Fault Diagnosis and Advanced Control

글 Springer 


\section{Contents}

Part I PEM Fuel Cells: Modeling, Simulation, Advanced Control, and Diagnosis

Introduction $\ldots \ldots \ldots \ldots \ldots \ldots \ldots \ldots \ldots \ldots \ldots$

Diego Feroldi, Marta Basualdo and Rachid Outbib

Description of PEM Fuel Cells System . . . . . . . . . . . . . . . . . 49

Diego Feroldi and Marta Basualdo

Advanced Control Strategies for the Oxygen in the Cathode. . . . . . . 73

Diego Feroldi, David Zumoffen and Marta Basualdo

Simulation and Control of PEMFCS Thermal Behavior . . . . . . . . . 117

Abdelkrim Salah, Rachid Outbib and Jaafar Gaber

Fault Diagnosis of PEM Fuel Cell . . . . . . . . . . . . . . . . . . 151

Andres Hernandez, Rachid Outbib and Daniel Hissel

Fault Diagnosis and Fault Tolerant Control of PEM

Fuel Cell Systems . . . . . . . . . . . . . . . . . . . . . . . 185

Diego Feroldi

Fuel Cell Hybrid Systems . . . . . . . . . . . . . . . . . . . . . . 207

Diego Feroldi

Energy Management Strategies for Fuel Cell Hybrid Systems. . . . . 233

Diego Feroldi 
Part II PEM Fuel Cells in the Context of the Fuel Processor System with Bio-Ethanol

Design and Control of an Integrated Bio-Ethanol Processor with PEMFC. . . . . . . . . . . . . . . . . . . . . 261

L. Nieto Degliuomini, S. Biset and M. Basualdo

Control Oriented Dynamic Model of the Bio-Ethanol

Processor System. . . . . . . . . . . . . . . . . . . . . . . . . . . . . . . . . 299

L. Nieto Degliuomini, S. Biset, P. Luppi and M. Basualdo

Mathematical Model Implementation for Simulation Purposes . . . . . 329

L. Nieto Degliuomini, S. Biset, D. Feroldi and M. Basualdo

Plant-Wide Control for Fuel Processor System with PEMFC:

Control Structure Selection and Optimal Sensor Location . . . . . . . . 361

L. Nieto Degliuomini, D. Zumoffen and M. Basualdo

Fault Detectability Index for Optimal Monitoring System Design . . . 405

D. Zumoffen. L. Nieto Degliuomini and M. Basualdo

Improved Principal Component Analysis Models for Fault

Detection Using Delay Adjustment .

E. Musulin and M. Basualdo

Index 